\title{
A duplicidade na técnica narrativa de Oswaldo França Júnior
}

\author{
Ângela Maria Salgueiro Marques \\ Universidade Federal de Minas Gerais
}

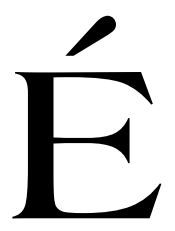

possível observar uma preocupação constante de Oswaldo França Júnior com a maneira de estruturar suas narrativas. Neste ensaio, serão analisadas três obras que se organizam de forma a enfatizar a questão da duplicidade. Essa duplicidade de que trataremos aqui diz respeito ao estado ou qualidade do que se apresenta com duas características, duas funções correlacionadas; e também como traço distintivo de quem se mostra de maneira diferente do que realmente é. Antes, porém, serão perseguidas algumas pistas que sinalizam para essa instigante questão. Duas delas se destacam de maneira muito clara: a dúvida e a interrogação que se repetem incessantemente, não só em vários contos como em alguns romances.

A repetição da descontinuidade ou de uma certa fragmentação como característica de algumas narrativas, tais como Aqui e em outros lugares ou No fundo das águas, difere da repetição que se encontra em muitas outras obras de França Júnior, entre elas as que selecionamos para este estudo: Os dois irmãos, A volta para Marilda e Jorge, um brasileiro. Esse dado parece revelar uma marca peculiar, passando a ser um motivo de grande interesse em sua ficção pois, vista sob o ângulo do duplo, a repetição nos remete a tudo aquilo que, estranhamente, é igual, mas diferente.

A interrogação, por exemplo, repetida inúmeras vezes e utilizada como um recurso estrutural, evoca a figura de pensamento conhecida como dubitação ou perplexidade. Nela, pode-se perceber a incerteza do narrador que se debate com pensamentos ou emoções contraditórios, exprimindo suas hesitações ou receios, ou uma certa vacilação no modo de se expressar. Esse modo é marcado não só pelas interrogações, mas também sob as formas exclamativa, condicional e reticencial. 
Aliás, como não recordar, aqui, de outras interrogações que deixam no ar intrigantes questões ao longo das breves narrativas de As laranjas iguais? Citemos as seguintes: o conto "O tempo lá fora" finaliza com a interrogação: "Agora não posso deixar que fechem a porta. De que modo gozarei o calor e o silêncio de minha casa, sabendo como está frio e como venta além destas paredes?" (p. 38). ${ }^{1}$ Outro exemplo: o conto "A evidência" também desconcerta, ao final: "E é por esse motivo que estou pensando: como, se seus cabelos estão molhados pelas ondas, seus pés têm vestígios de todas as estradas e no seio ela amamenta uma criança?"(p. 82).

Recorde-se que a indagação contida na epígrafe de As laranjas iguais, por sua vez, novamente vai-se fazer presente no romance $\grave{A}$ procura dos motivos. Nele, a busca por explicações para se tentar descobrir o motivo que leva um pai a abandonar a família de maneira inexplicável é a tônica dessa narrativa. Assim, a interrogação passa a ter uma direção convergente, mas com a diferença de que a personagem Carmem vai em busca de explicações para tentar entender o diferente comportamento do pai. Auxiliada por relatos alheios, ela tenta recompor a imagem paterna que não condiz com a atitude de certos procedimentos repetitivos e sempre previsíveis daquele homem de cinqüenta e seis anos, que levava uma vida de trabalho metódico, paciente, antes de abandonar a família. Isso esclarece que as interrogações não se limitam apenas a alguns contos. Assim, não será difícil perceber, nos romances já mencionados de Oswaldo França Júnior, a presença de alguns elementos que se voltam para a repetição, direcionada para o mito, na tentativa de referendar esse eterno retorno ao mesmo, ao idêntico. Muitos desses elementos podem ser observados pelas perguntas que se fazem presentes na condução narrativa de alguns romances, como em $\bar{A}$ procura dos motivos e A volta para Marilda, no final do romance Os dois irmãos, ou ainda na epígrafe do livro de contos, As laranjas iguais, bem como em inúmeros contos.

Podemos, então, ressaltar o fato de que a estruturação da narrativa nas obras de Oswaldo França Júnior é, ela mesma, uma construção reflexiva que, ao privilegiar a dúvida e a indagação, procura reunir diversos fios soltos das histórias e perspectivas que conferem o caráter de

${ }^{1}$ Opto, em vista dos inúmeros exemplos extraídos das obras de Oswaldo França Júnior, por citá-los, entre parênteses, no corpo do texto. 
pluralidade ao universo narrativo de suas obras. Um ininterrupto movimento de aproximação e afastamento dessas perspectivas dá origem à uma inquietação que ultrapassa o texto e confere complexidade a uma narrativa que, a princípio, aparenta ser marcada pela simplicidade.

\section{Os dois irmãos: repetição e violência}

A duplicidade que podemos entrever em Os dois irmãos pode ser apreendida através da presença de duas funções correlacionadas, ou da coexistência de duas posições contrárias, opostas, ou de um fazer em duplicado ou do fazer repetidas vezes. Esse fazer em duplicado pode ser percebido no que se refere à técnica narrativa, ou seja, há dois níveis da narração que se intercalam no texto: a revisitação constante ao irmão e, em seguida, o reconto dessas visitas à mulher. Essas duas histórias acontecem como narrativas paralelas, exemplificando as duas funções correlacionadas. As duas histórias caminham sempre juntas na maioria dos dezoito capítulos, com exceção apenas dos capítulos 6, 10 e 11. As posições contrárias se mostram na dualidade do cenário: campo versus cidade, e na oposição do caráter dos irmãos: o homem, precavido, sempre com os pés no chão, ao passo que o irmão é um aventureiro, um sonhador, incapaz de pensar no dia de amanhã. Os dois níveis de narração presentes no texto são assim explicados por John Parker:

[O homem] é um focalizador interno na medida em que ele funciona como narratário em relação às histórias que ouve. Ele procura seu irmão, conversa com ele, questiona seu procedimento, ouve suas respostas, ou também ouve histórias contadas por outros personagens, surgidos no livro apenas para contar uma história. Estas histórias não são comentadas pelo narrador extradiegético e "o homem", se as comenta, é para as achar estranhas, deixando-nos a impressão de serem exemplares, de conterem alguma verdade cuja interpretação depende do leitor. ${ }^{2}$

Nem todas as historietas ouvidas pelo homem e narradas por personagens relacionadas ao convívio habitual do irmão (todas elas têm nome), são comentadas pelo homem com sua mulher. Parece-nos

${ }^{2}$ PARKER, 1996, p. 144. 
importante enfatizar, no entanto, a recorrência de algumas cenas de violência lembradas pelo irmão e que impressionam sobremodo o homem. Essas cenas, repetidas em seis capítulos, referem-se à violência praticada por homens contra filhos, mulheres e pessoas da comunidade em geral. São elas: no capítulo VI, em que não há a conversa com a mulher, o homem e o irmão visitam uma personagem de nome Alcides. Este conta que sua mulher perdera um menino e adotara um sobrinho que foi morar com eles, para fazer-lhes companhia. E Alcides comenta que o pai do rapazinho batia muito na mulher. Ela não resistiu e morreu. "- Eles falam que toda noite ele cortava uma taquara e batia nela. Depois ela ficou com barriga-d'água e foi para a Santa Casa de São João e lá ela morreu" (p. 42).

No capítulo VIII, o homem vai com o irmão ao enterro de um fazendeiro. E pergunta ao irmão quem era um indivíduo que mancava ao lado do caixão. O irmão explica que era o filho do fazendeiro e que este era muito violento. E falou do tiro que ele havia dado no filho. "Do tiro que uma vez tinha dado no filho mais novo quando voltou de um serviço e o encontrou em cima de seu cavalo" (p. 58).

O capítulo X conta a história de um rapaz, de nome Henrique, cujo pai havia sido um homem muito truculento. Um dia, esse pai brigou com o filho de uma velha. Havia batido nele com um pedaço de pau. Bateu até ele cair. Quebrou a cabeça e a testa do filho da velha. "- Deixou o moço com um amassado na cabeça e o olho do lado direito torto, mas não chegou a matar" (p. 75).

Elias, tirador de músicas da Folia de Reis, era o pai de Maria, mulher do irmão. Também era um pai muito violento e todo o capítulo XIV é dedicado ao relato de como era a vida dessa personagem tão contraditória: guia, benzedor, andarilho, cantador, violento, valente e sedutor. Maria conta que ele - "Sabia fazer rezas e era também muito forte". E o irmão explicou que o pai de Maria não gostava dela. Achava que ela não se parecia com ele. E o irmão continuou:

E em muitas noites tirava a coberta de cima dela e levava para sua irmã. E Maria tinha que se cobrir com a lona que cobria o milho. Uma vez ele chegou em casa e encontrou-a brigando com a irmã. Segurou-a pelos ombros e bateu com força sua cabeça na madeira da porta. E ela desmaiou.

- Ela quebrou a cabeça e um farmacêutico é que tratou dela. Deu pontos e amarrou um pano em volta da sua cabeça. 
E o irmão disse que quando a conheceu ela estava com o pano amarrado em volta da cabeça.

- Ela não tinha sarado ainda. Estava com os olhos inchados e sentia muitas dores.

E o irmão falou que nas noites de lua crescente ela ainda sentia a cabeça latejar. O homem ouvia o irmão e pensava: "Vou dizer isto à minha mulher quando chegar em casa." (p. 102-103).

É interessante notar a colocação do pensamento do homem entre aspas, demonstrando o quanto ficara impressionado com a violência do pai de Maria. Mas, esse é um tipo de estratégia narrativa que quebra a repetição paralela do romance, ou seja, todo pensamento do homem, enquanto reflete sozinho sobre o irmão, a respeito das situações que lhe despertam no íntimo um estranhamento e um certo mal-estar são colocadas entre aspas. Vale lembrar aqui outras reflexões do homem: "O que vai fazer ele agora, meu Deus? Irá fazer outra represa mais em cima e quando encontrar uma pedra chamá-la outra vez de pingo d'água? E depois colocá-la num ninho de lama e ficar esperando que sirva de chamariz para as outras?" E o homem pensou: "Por que é assim, meu Deus?" (p. 18-19). O homem reparou no irmão e pensou: "O padre não irá nunca convencê-lo de nada. Ele não o escuta" (p. 45). E o homem pensou: "Por que ele também não procura as pedras? São tantos os que encontram cristais, por que ele não faz o que todos estão fazendo?" (p. 52). O homem estranhou quando encontrou o irmão conversando com três irmãs velhas. Elas o tratavam como a um amigo e o homem pensou: "Por que ele dá atenção a elas que não sabem nada?" E pensava: "O que elas podem dizer a ele que seja de utilidade? Três velhas que moram sozinhas e quase não falam com ninguém" (p. 83). Ao conversar com o irmão sobre o tempo em que eram jovens e viviam com o pai, o homem teve vontade de lembrar mais coisas, mas algo o impediu. E ele pensou: "Vou voltar para casa. Vou sair daqui e voltar para minha casa" (p. 122). Esse algo parece se referir a um indício sobre a violência do pai, fato que, entretanto, o homem vai postergando, até chegar ao final do livro. E o homem pensou: "Se as lembranças que ele tinha de nossa mãe eram essas, por que naquele dia rezou pela sua alma?" (p. 124). E pensou: "Eu e meu irmão crescemos na mesma casa, mas há muitas coisas que (sic) apenas eu me lembro" (p. 125). E o homem havia pensado: "Será que os gritos do nosso pai o marcaram tão fundo, assim?" (p. 128). O que importa destacar é que as aspas recortam de maneira enfática tudo que se refere 
aos pensamentos do homem. Isso fica muito salientado pelo verbo dicendi - "o homem pensou", em todos os exemplos citados.

A atitude reflexiva dessa personagem "o homem" nos reenvia para a questão marcante que distingue o "Homem" (no sentido genérico) da forma animal. Através do pensamento, o "Homem" consegue estabelecer diferenças entre si e os demais elementos da natureza como também se coloca como um ser distinto de todos os homens em geral. Segundo Martin Esslin, o motivo do duplo (doppelgänger motif), baseado apenas na identidade física externa é a forma mais simplista e primitiva na qual permanece a imaginação humana na literatura. E esclarece por quê:

Assim, nesse sentido, o que esse motivo representa é o eterno desejo humano de experimentar seu próprio self como se ele fosse um outro, confrontar-se objetivamente ao invés de subjetivamente. Isso, essencialmente, é o que todos nós temos de fazer, quando estamos pensando sobre nós mesmos, ou simplesmente, quando estamos atentos ao que estamos fazendo ou pensando. A consciência ela mesma, em sua forma humana - enquanto distinta da forma animal é um processo de autoconsciência, de auto-observação, uma cisão da mente em um observador que se auto-observa como objeto de sua observação, seus próprios pensamentos e ações. No romance ou no poema épico esse processo é facilmente representado pelo instrumento da descrição daquilo que se passa na mente do personagem: "ele disse a si mesmo", "ele sentiu", "ele pensou" são indicadores estilísticos dessa dualidade. ${ }^{3}$

Como se vê, a explicação de Martin Esslin para a cisão que ocorre na mente de um observador que se auto-observa também nos convida a refletir sobre os verbos dicendi que articulam os dois níveis da dualidade. É importante ressaltar que a conversa com a mulher se apresenta de maneira sintética, como se fosse um resumo do que o homem viu e ouviu, estabelecendo um ponto de contato entre as duas narrativas paralelas. A mulher, então, passa a assumir a função de narratária a acolher quase todos os questionamentos do homem relacionados ao irmão.

As dúvidas dirigidas à mulher, no entanto, continuam latentes, pois, ao conversar com o marido, a esposa pede algumas explicações sobre o procedimento do irmão e não raro revela um pensamento crítico próprio,

${ }^{3}$ ESSLIN, 1984, p. 39. (Tradução de Ângela Cristina Salgueiro Marques). 
fazendo com que o homem continue perplexo diante do comportamento irredutível do irmão. Como nestes exemplos: o homem comenta que Maria e o irmão começaram a trabalhar numa lavra de cristal. Maria servia pratos de almoço e jantar, enquanto o irmão "andava à toa". Mas ela aceitava tudo e não reclamava. A mulher do homem então comenta: "- Talvez ele já a tenha convencido das histórias em que acredita." O homem pensou e disse: "-Talvez seja isto. Talvez ele já a tenha convencido dessas histórias" (p. 54).

De outra feita, o homem conta à mulher que o irmão carregava um ferido dentro de uma rede, para levá-lo ao médico. Ao que a mulher responde: "- Então seu irmão, hoje, estava ajudando a uma pessoa." O homem comenta: "-É, hoje ele não estava andando à toa. Hoje ele estava ajudando a uma pessoa." A mulher diz: "- E isto é bom." O homem finaliza: "-É - concordou o homem. - Isto é bom" (p. 71). Ou, quando o homem relata para a mulher a violência do pai da Maria, ela lamenta: "- Ele não era uma pessoa boa". E ele concorda: "- Não, não era uma pessoa boa" (p. 106). Os exemplos acima registram um outro nível de duplicação que ocorre nesse romance, já que o homem ecoa as palavras da mulher, e esse é um aspecto que importa salientar: a presença de uma fala que se repete literalmente. Ressalte-se ainda que o eco é uma figura de linguagem que comprova o efeito sonoro da repetição.

Por outro lado, as várias histórias em que se nota a repetição constante da temática relativa a pais violentos parecem prenunciar uma linha de significação muito marcante na vida desses dois irmãos e na trama narrativa. Trata-se da violência do próprio pai em relação à mãe de ambos. Dessa forma, as histórias a circular dentro da história principal - o enterro do pai, a procura do irmão, o encontro, a falta de diálogo e a desistência - atuam como reduplicação especular, numa forma de intertextualidade interna, a prognosticar a dor de uma reminiscência ainda não superada pelos irmãos: a imagem do pai violento, bêbado e que vivia batendo na mãe.

- Aquela sem-vergonha - ele gritava. - Ela fazia aniversário no dia 15 de junho.

Era isto o que o irmão conhecia. Era o que o pai gritava de dentro de sua bebedeira. E o homem lembrava que dizia:

- Não ligue para o que ele está falando. Ele está bêbado. (p. 124).

Mas o irmão pressentia haver algo estranho: “- Os meninos disseram que minha mãe era a Ana da Porteira” (p. 127). E ele não reagia 
contra esse nome. Os gritos do pai pareciam a tudo abafar. Os dois, contudo, tentam fazer vir à tona outras lembranças da infância. O homem então pergunta ao irmão se ele se lembrava "de quando andava na chuva tentando colocar os pés nas marcas que os sapatos do nosso pai deixavam em frente da porta?" E o irmão responde: "- Disto eu me lembro. Das marcas que os sapatos dele deixavam nos dias de chuva, eu me lembro" (p. 122).

A atitude do irmão que tentava preencher com os próprios pés as marcas deixadas pelos sapatos do pai evoca a luta pela posse do lugar do pai, de que nos fala Freud, em Totem e Tabu. É uma imagem forte que persiste em sua memória, ao passo que outras são relegadas ao esquecimento: "- Das marcas que os sapatos de nosso pai deixavam no chão, eu me lembro. E de ter vindo ajudar a velha Noelma, eu não me lembro" (p. 122).

No capítulo IV, quando o homem tenta se aproximar do irmão para iniciar um diálogo, ele relembra uma história que ouviram quando crianças. Mas eles sabiam da história até um certo ponto, porque a pessoa que narrava a história deixou a parte final para o outro dia. Mas não voltou à casa deles na noite seguinte. O homem pensou que essa história (até o ponto em que a conheciam) fosse um elo de aproximação entre eles. "E procurou continuar prendendo a atenção do irmão. Procurou uma semelhança entre as coisas que aconteciam na história e as que ocorriam entre eles. Mas não encontrou" (p. 26). Essa história - um pássaro que feriu os pés na lâmina de uma faca esquecida no parapeito da janela onde pousou - parece sugerir um elo perdido. A menina que gostava do pássaro teve medo de que ele não mais voltasse. E arquitetou um plano. Os irmãos sabiam da história até este ponto. Um ponto que indicia a falta de um ponto final: para a história do pássaro e para a vida de cada um dos irmãos. O romance termina com a pergunta angustiante do homem: "- Deus, o que eu faço para esquecer o meu irmão?" (p. 131).

A circularidade do romance se manifesta no tempo: a narrativa começa in media res - no meio do enterro do pai, e termina com o narrador relatando a noite que antecede a morte do pai, e o momento em que o homem retorna à casa, pensando no irmão.

A recorrência das histórias em que a ênfase recai sobre os pais violentos parece confirmar a imagem que os irmãos têm do próprio pai, enquanto se prepara a difícil hora que ambos têm de enfrentar: verbalizar a dor que vivenciaram durante o período da infância. A obra de Oswaldo 
França Júnior, no entanto, não está circunscrita apenas ao âmbito da discussão de questões domésticas, pois ela também se insere na literatura contemporânea, ao focalizar alguns aspectos da violência que são marcas características da década de 70 . Senão vejamos o que nos diz Karl Schöllhammer:

Durante a década de 70 , a prosa sobre a violência dirige-se, alegoricamente, contra um sistema político autoritário e a violência urbana é ressaltada como meio de expressão contra um poder anônimo e institucional. Nos anos 80 , a temática da violência urbana toma outros rumos: torna-se objeto de interesse pela sua própria natureza associal e irracional, e semente de novos focos de articulação social através da ritualidade, do jogo, do sacrifício e do erotismo. ${ }^{4}$

É verdade que em pelo menos duas obras de França Júnior é possível perceber a violência perpetrada por um sistema político autoritário, mesmo que não seja de forma tão explícita como a encontrada em outras obras de vários escritores brasileiros que se dedicaram a esse tema, tais como Fernando Gabeira, Marcelo Rubens Paiva, entre outros. França Júnior aborda esse tipo de violência, de maneira alegórica, em $O$ Passo-Bandeira e em Um dia no Rio. Cabe aqui uma observação muito interessante de Vera Lúcia Felício Pereira, a respeito do romance O PassoBandeira, no qual o avião C-47, comandado pelo Coronel Ladeira, cai, dizimando todos os ocupantes. Esse avião é comparado pela ensaísta a uma arca, a Arca de Noé, pois levava representantes das forças que, à época, dominavam o Brasil. São dezenove passageiros, quatro tripulantes e alguns animais.

Estarão representados, na aeronave, o Exército, a Marinha e a Aeronáutica - esta pelo único casal visto com simpatia, mas estéril -, a Igreja - irmãs de caridade de longos hábitos tradicionais -, os indígenas - um menino de perna amputada e um cacique velho -, animais sem fêmeas, a Funai, o Incra, um cinegrafista e seu auxiliar e um caixote de mangas. ${ }^{5}$

A alegoria é bem significativa aqui, as personagens são escolhidas com uma sutil irreverência e um cortante senso de humor e, ao contrário

\footnotetext{
${ }^{4}$ SCHÖLLHAMMER, 1994-1995, p. 289.

5 PEREIRA, 1983, p. 20.
} 
do mito bíblico, há uma velada ironia da situação política reinante no país. A "Arca" foi sendo esvaziada aos poucos, assim que a hélice do avião recusa-se a entrar em passo-bandeira. Passo-bandeira, título do romance, é uma posição em que se coloca as pás da hélice depois que o motor deixa de funcionar. Para que isso aconteça, é necessário virar para a frente o fio das pás da hélice, utilizando-se a eletricidade das baterias. Dessa forma, esse fio vai cortando o ar, não oferecendo resistência ao avanço do avião. Como o piloto não conseguiu solucionar essa pane, o que faz com que o avião vá perdendo altura lentamente, a queda torna-se inevitável, o que faz perecer todos os seus ocupantes. É o que observa Vera Lúcia Pereira: "Exatamente como se definhou a revolta de 64, desfeita em seu próprio interior pelas ações daqueles que a fizeram e que, desacreditados, arruinaram não só a si mesmos, como também vidas inocentes, significadas no avião, pelas crianças." ${ }^{6}$

Em Um dia no Rio, as cenas de violência da polícia contra os estudantes em 1968, apesar de serem descritas com muito realismo, estão ali mais para indicar um obstáculo a ser vencido pelos irmãos Márcio e Lúcio, que se perdem no meio da confusão, do que para serem narradas de maneira a que houvesse um juízo de valor. Aliás, em nenhum momento se percebe, nem por parte da personagem principal, nem pelo narrador extradiegético, qualquer comentário crítico. A observação acima também se mostra muito evidente na relação supostamente fraterna das personagens do romance Os dois irmãos. Desde o início da narrativa, pode-se notar a atitude dominante do "homem" que se arvora como o dono da verdade, do caminho certo que somente ele trilha, do dinheiro seguro no final do mês, enfim, a crença de que o irmão deve segui-lo a qualquer custo. Mas, isso é só uma impressão. Veja-se, no diálogo a seguir, como o irmão desconcerta o homem:

E [o homem] contou [à mulher] que uma vez havia dito ao irmão:

- Você ouve as histórias desse velho, mesmo sabendo que ele não pode ser levado a sério e não escuta o que eu falo.

E que o irmão havia respondido:

- Você tem certeza que (sic) ele não pode ser levado a sério?

- E eu estranhei isso - disse o homem à sua mulher (p. 27).

${ }^{6}$ PEREIRA, 1983, p. 20. 
Em várias outras passagens do romance, é possível notar algumas poucas, é verdade, opiniões do irmão que desconcertam o homem, diante das quais ele não consegue replicar. Trata-se de mais uma característica da modernidade de França Júnior, pois seus narradores raras vezes detêm uma única visão das coisas, fazendo com que o leitor ora compartilhe seu ponto de vista com uma determinada personagem ora com outra. Assim, a duplicidade presente nesse romance apresenta a potencialidade de influir na interpretação construída pelo leitor. Cumpre ainda observar que, apesar de ser possível perceber uma função de focalizador ideológico nos romances narrados em primeira pessoa, John Parker constatou que, nas obras posteriores a A volta para Marilda (com exceção de Recordações de amar em $\mathrm{Cuba}$ ), França Júnior "parece ter começado a duvidar de certos valores colocados em seus livros", verificando-se então a "ausência de uma voz afirmativa e uma certa fragmentação narrativa."

É importante termos sempre em mente que a estrutura narrativa das três obras que escolhemos para análise se desenvolve em torno da duplicidade, ou seja, há uma presença marcante de pontos de vista, situações e vivências que, ao mesmo tempo, se interceptam e se distanciam. Essa tensão, evidenciada pelo desconcerto mútuo entre as personagens, muitas vezes se confunde com o duplo, pois este, além da duplicidade na narrativa, pode ser apreendido em dois outros níveis distintos: a alteridade e a repetição, ambas fundamentais para a afirmação do sujeito e para o surgimento da diferença que o distingue como único, singular.

\section{A volta para Marilda: repetição e artifício}

Os dois níveis estruturais do romance $A$ volta para Marilda - o diegético e o intradiegético - permitem entrever uma história que se conta de modo estratégico devido à escolha da maneira de narrar, que revela a duplicidade como característica de quem se apresenta de maneira diferente do que é. Esse é o artifício utilizado pelo narrador de A volta para Marilda. Um narrador que, ao tentar recuperar os fragmentos desordenados de sua experiência amorosa, compõe uma narrativa estratificada que, ora

${ }^{7}$ PARKER, 1996, p. 145-146. 
se volta para a ação principal, ora se detém nas tramas secundárias que servem para complementá-la. Dessa forma, o narrador-personagem mostra-se ardiloso, ambíguo, dúbio.

A estrutura narrativa desse romance se constrói a partir da tensão entre "o que já ocorreu" e as "ações recuperadas" de modo seletivo pelo narrador. Sendo assim, ele começa a contar sua história, conduzindo o leitor em meio ao resgate de episódios aleatórios responsáveis por esclarecer ou obscurecer a ação principal. Esta diz respeito ao rompimento amoroso entre o narrador e sua amada, Marilda. É possível perceber dois níveis na condução narrativa desse conflito: o narrador, através do ato reflexivo de recompor seu envolvimento com Marilda, é obrigado a repassar os pontos fortes e fracos tanto de sua personalidade quanto de sua relação amorosa. Por outro lado, o "mau caráter" de Marilda é delineado somente através de "pistas" e opiniões formuladas por terceiros. Talvez seja essa a razão de um certo descrédito do narrador, pois, conforme observa Malcolm Silverman:

Em A volta para Marilda, o inoportuno (e não merecedor de confiança) protagonista-narrador tenta inocentar a personagem-título, a propósito do conserto de sua casa: "E eu também é que estava me oferecendo. Ela não pediu nada" (p. 41). Essa visão, no entanto, choca-se com a de sua família, aqui representada pela antagônica irmã, mas repetida através da história em termos semelhantes: "- Aquela sem-vergonha, aproveitadora. Fica fazendo você de burro de carga" (p. 14). Ficamos imaginando como será a verdadeira Marilda. ${ }^{8}$

Essa também parece ser a principal característica desse romance, que reduplica a personalidade de suas personagens principais, refletindo assim uma estrutura dúplice que exige do leitor uma certa perspicácia para ler nas entrelinhas. Assim explica John Parker:

É sobretudo o caso de A volta para Marilda, onde o narrador parece pensar em voz alta e a narrativa prossegue, simultaneamente, em dois níveis: a narração cronológica dos fatos, que assegura a estrutura formal do romance, e a corrente aparentemente arbitrária, o vai-e-vem, dos pensamentos e das lembranças do personagem, os quais retornam, mesmo assim, a todo momento, em direção à Marilda, como sugere o título do romance.?

\footnotetext{
${ }^{8}$ SILVERMAN, 1978, p. 203.

9 PARKER, 2002, p. 5 (Tradução nossa).
} 
Ao longo da narrativa, que se desenrola como um monólogo, o leitor segue sem saber a causa imediata da briga entre o casal, já que o narrador se aproxima do motivo, dando pistas para elucidá-lo, mas logo depois afasta-se dele, desviando o assunto para outras histórias paralelas. "Tínhamos tido aquela briga toda na véspera, mas ela é uma mulher inteligente. Era para ter visto que se eu estava ali, se tinha aparecido logo pela manhã, era porque estava querendo fazer as pazes" (p. 9). E acrescenta mais à frente da narrativa: "E foi uma pena porque a gente vivia tão bem, sem discussão, sem briga. Um querendo sempre agradar ao outro. Ela tinha que se lembrar disso. Afinal, quem terminou a casa para ela fui eu" (p. 49).

Os exemplos acima demonstram um narrador que protela as informações importantes sobre a causa do desentendimento entre eles, enquanto assegura sua inocência. Esse fato confirma a duplicidade de que tratamos nesse item: a característica daquele que, ao ressaltar suas qualidades, sustenta o fio da narrativa sob um véu de dissimulação. E esse narrador reúne o máximo de virtudes, conforme seu veemente testemunho: "E eu não merecia aquilo. Eu sou uma pessoa boa. Todo mundo que me conhece sabe que eu sou bom. Me preocupo com os outros. (...) Eu sou uma pessoa de coração bom" (p. 48). E como se comprova, quando o narrador comenta sobre o serviço que sabe fazer: "Mas eu sou bom para fazer as coisas. A primeira vez que cobri [o telhado] também ficou bom. Também ficou um serviço bem-feito" (p. 64). E volta a reafirmar quase nas páginas finais: "Tudo coisa bem-feita. Os serviços ruins que saíram ali foram os que eu mandei fazer. Foram os que os outros fizeram. Onde eu coloquei a mão, saiu bem-feito. O que eu fiz, foi com capricho" (p. 106).

$\mathrm{E}$, para se certificar de que suas qualidades são verdadeiramente as melhores, o narrador se vangloria, tecendo comparações com os outros: "Controlo os empregados, olho, vigio, chamo a atenção deles, mas não choro dificuldades. Não uso golpes sujos, golpes de joão-sem-braço, para atrasar o pagamento deles, como o Sr. Milton fazia" (p. 98). É exatamente isso o que é ressaltado por Maria Angélica Lopes, ao observar como o narrador tece sua auto-afirmação por meio da desqualificação de outras personagens:

Este narrador homodiegético também se descreve (principalmente em contraste com as outras personagens) como modelo de virtude: trabalhador, ao contrário de Leda, Rozana e vários outros; não fala mal 
dos outros (como Leda, Rozana e os pais de Marilda); não é ladrão como o Sr. Milton, nem bobo como o vizinho que apanha da mulher. Sente-se, desde o início, leve, mas persistente olor hagiográfico, que sugere ao leitor que este narrador não é fidedigno. Se ele e Marilda são modelares, como chegaram a se desentender? ${ }^{10}$

Ao invés de continuar falando mal dos outros, muitas vezes o narrador interrompe esse tipo de estratégia, para inserir, na narrativa, um elogio a Marilda: "Que mulher inteligente, meu Deus. Nunca vou encontrar outra igual. Posso procurar a vida toda que não encontro, eu sei disso" p. 52). Esse julgamento reflete exatamente a valorização que o narrador tem de si: "Ela não teve a consideração que eu esperava. Foi malagradecida. Mas já deve ter pago. Já deve ter visto que encontrar um outro como eu é difícil. Não é fácil. Já está arrependida" (p. 11). Observe-se, com esses exemplos, como ambas as opiniões do narrador ecoam o mesmo juízo de valor. O elogio à amada, no entanto, não condiz com o conceito que sua mãe e a irmã Leda fazem de Marilda: "Aquela sem-vergonha, aproveitadora. Fica fazendo você de burro de carga" (p. 13). Com isso, ele se mantém em silêncio e passa a responder-lhes apenas com monossílabos.

O juízo que a mãe e Leda faziam de sua companheira, por sua vez, estabelece um paralelismo com os vitupérios proferidos pelo pai de Marilda, na manhã seguinte em que o narrador resolveu procurar a amante: "vigarista, vagabundo, aproveitador" (p. 7-8). Aqui também se verifica um eco que se propaga pelo uso de vocábulos pertencentes ao mesmo campo semântico, escolhidos pela mãe e a irmã Leda, ao qualificarem Marilda. É oportuno ressaltar, nesse contexto, a afirmação de André Green, ao escrever o prefácio da obra $O$ duplo, de Dostoievski: "Deste modo, antes de ser uma aparência, o duplo é, em primeiro lugar, uma voz." ${ }^{11}$ Ele chega a essa conclusão, ao assinalar a repetição de uma frase ("lhe dizia mesmo qualquer coisa, lhe dizia qualquer coisa"), observando como a escrita se reveza com a representação da cena, no momento em que o Duplo se manifesta como presença invisível para Goliadkine. Como uma voz que se propaga no interior dessa narrativa, tem-se novamente a figura do eco a engendrar um duplo diferente da maioria dos exemplos que observamos até então.

${ }^{10}$ LOPES, 1991, p. 27.

${ }^{11}$ GREEN, apud DOSTOIEVSKI, 2002, p. 24. (Tradução nossa). 
O sogro, entretanto, ao fazer coro com as vozes da mãe e da irmã do narrador, parece estar bem fundamentado em suas razões, pois o narrador acaba confessando, já no meio de seu relato: "Escondi o dinheiro da Marilda para depois gastar comigo, fazendo papel de bobo. Um dinheiro que era dela, não era meu" (p. 51). E depois confessa: "Quando me lembro de ter feito essas coisas com ela, sinto até vergonha" (p. 52). "Essas coisas" sugerem a inclusão de algo bem mais forte que esconder dinheiro da amante. Vale lembrar que o narrador escondia dinheiro dentro de um saco plástico e depois o colocava debaixo de uma telha do teto da cozinha, à noite, enquanto Marilda dormia. Esse "esconder dinheiro", aos poucos, diariamente, guarda uma similaridade com o ato de recompor estilhaços de uma rotina, os quais se vão juntando como a formar um quebra-cabeça, exigindo, pois, um trabalho de paciência. É uma tentativa de dar forma ao passado, através de esquemas narrativos que vão-se agrupando, num fluxo de memórias que é próprio daquele que organiza mentalmente a experiência vivenciada.

A partir de então, aos poucos, o narrador vai redesenhando o perfil da companheira e, afinal, resolve admitir: Marilda era tão ciumenta que não gostava que ele mostrasse as roseiras para as alunas de culinária, a quem ela dava cursos. Além disso, ela também chegou ao ponto de desistir de criar uma menina, justificando: "- Fico com ela [a menina] e depois, quando estiver uma moça bem bonita, você vai e dá de cima dela" (p. 110). E, no dia em que ele chegou tarde a casa, aborrecido por ter pago sozinho a conta do bar, Marilda começou a reclamar: "- Eu estou vendo que você não gosta mais de mim, você arranjou outra. (...) Não liga mais para mim, não traz mais as coisas para a casa. Olhe hoje: está chegando a essa hora e ainda cheirando a bebida. Você não é mais como era antes" (p. 117). O homem não agüentou e partiu para a violência.

Vê-se, pois, que a dupla construção desse romance, já estudada por Maria Angélica Lopes e John Parker, alude a uma associação com o motivo do duplo inter-relacionando-o com os "motivos" que agem como peças cumulativas, tanto na sugestão do caráter dúbio das personagens quanto na dúplice estrutura narrativa. E o "motivo" principal da briga com a Marilda só será revelado no penúltimo parágrafo do romance, quando o narrador enfim retira sua máscara:

A Marilda podia ser muito boa, mas naquele dia ela abusou. E eu estava nervoso. Chutei a cadeira, pronto. Mas isso não era nada demais. Qualquer um podia fazer. Eu estava com raiva. E ela em vez de ir para 
longe, não, ainda veio para mais perto, para junto de mim. Bati nela. Não devia ter batido, mas bati. O que eu posso fazer? Machuquei o rosto dela. E daí? Adiantou ela ir atrás do pai? Adiantou chamar aquele carcamano? O que resolveu foi que agora ela está aí sozinha, mandando recados, passando apertos. (p. 117-118).

Mais uma vez, o fragmento acima revela a violência da intimidade familiar, uma violência que atinge em cheio a face de uma mulher. Em outro romance de Oswaldo França Júnior, essa violência se expande e acaba deixando o círculo doméstico, ganhando visibilidade no ambiente de trabalho e na luta de uma personagem em busca de sua identidade e que será analisado no próximo item deste ensaio.

Mas, se observarmos os planos narrativos de A volta para Marilda e compará-los com os de Os dois irmãos, pode-se ver que o narrador, companheiro de Marilda, é um narrador que usa de dissimulação para adiar a versão dos fatos revelada no trecho final do romance. Com isso, retomamos a tensão existente entre os dois níveis da narrativa, somados a duas formas de artifício: a) recuperar ações que deveriam elucidar a ação principal, mas que acabam gerando dubiedade; b) perceber que a caracterização das personagens revela uma suspensão da diferença entre o que elas "são" ou "demonstram ser" e que não se define apenas sob o ponto de vista do narrador. São, por outro lado, também mosaicos resultantes do imbricamento das opiniões que o narrador recolhe, ao ativar o fluxo de suas memórias, na tentativa de organizá-las narrativamente. E esse imbricamento se torna um artifício pela forma com que o narrador vai reconstruindo as personagens, ao longo da trama, ou seja, no cruzamento dos níveis diegético e intradiegético. É esse intercalar que garante a duplicidade, uma vez que as ações e sentimentos são sempre resgatados de modo fragmentado e parcial.

\section{Jorge, um brasileiro: repetição, circularidade e diferença}

Jorge, um brasileiro, sem dúvida um dos melhores romances de França Júnior, tanto que lhe rendeu o prêmio WALMAP de 1967, patrocinado por José Luís de Magalhães Lins e o Banco Nacional de Minas Gerais, representou uma novidade em nossa ficção. A comissão julgadora era formada por Antônio Olinto, Jorge Amado e Guimarães Rosa. Retomo 
aqui as palavras de Antônio Olinto ao elogiar esse "novo romance brasileiro" que, para o crítico, nada tem a ver com o nouveau roman, seu congênere francês:

A história vai do começo ao fim de uma só vez. Não há divisões de capítulos nem retenção do fluxo da narrativa. Sem parar, o narrador começa a falar (a impressão do leitor se fixa mais no estar ouvindo do que no estar lendo) e, falando, chega, quase no mesmo fôlego, ao término do que tinha a dizer. O narrador fala para cada um, chama esse cada um de "você", interrompe um caso e, como acontece nos relatos orais, parece ter perdido o fio da meada (e o leitor-ouvinte pensa que ele não mais conseguirá reatar a corrente da estória), mas volta ao caso anterior, às vezes, sem haver terminado o que se intercalara (e o leitorouvinte torna a achar que, desta vez, o caso do meio é que ficará sem fim). Depois de muitas veredas de estórias, porém, de muito caso-puxacaso e de uma série de considerações intermediárias, o narrador fecha o romance com extraordinário senso de completidão sem, contudo, encerrá-lo por completo. ${ }^{12}$

Essa história sugere um jogo de quebra-cabeças: casos e mais casos se imbricando e se interpolando formam um todo com seus encaixes narrativos. Digna de nota é essa outra observação de Antônio Olinto, referente à estrutura do romance, a qual lembra "um traçado também rodoviário, com estradas principais e variantes, entradas em caminhos secundários, e voltas deles" ${ }^{13} \mathrm{O}$ espaço predominante nessa narrativa é a estrada. A personagem Jorge não é um simples passante por esses caminhos rodoviários. Ele mesmo ajudou a construir a estrada por onde passa e registra sua contribuição, comentando com seu interlocutor:

E passando por uma estrada em que eu tinha andado muito, e até ajudado a construir, fiquei pensando. E pensei que trabalhar em estradas não é como outro serviço, que você faz um trabalho, e se é num prédio, o prédio que está do lado parece que você nunca esteve perto dele. Mas estrada eu sempre achei que tudo é uma coisa só. E se você ajuda a fazer a ponta dela, a outra ponta também parece que tem serviço seu, e que também é um pouco sua. $\mathrm{E}$ o aterro onde você ficou jogando terra, é irmão do outro, e do outro em que você vai passando. Está entendendo? É, a coisa é assim (p. 106-107).

${ }^{12}$ OLINTO, apud FRANÇA JÚNIOR, 1967, p. 13.

13 OLINTO, apud FRANÇA JÚNIOR, 1967, p. 14. 
Ora, nada mais significativo do que a explicação dada pela personagem Jorge, para ilustrar a circularidade de que é feito o romance Jorge, um brasileiro. Se a mesma estrada é caminho de ida e de volta, as duas pontas de que são feitas redefinem o caminho circular dos passantes que podem ir e voltar. E é inspirado nesse mesmo caminho que o caminhoneiro Jorge ata as pontas de seu longo relato, sem se perder pelos atalhos.

O fluxo da narrativa é como o fluxo de uma viagem ininterrupta. Isso condiz com a expressão popular "caso-puxa-caso" e nos remete à figura intrigante da famosa personagem das Mil e uma noites: Sherazade conta uma história na qual se conta uma história na qual se conta uma história, indefinidamente.

Ao elogiar a grande invenção de Laurence Sterne que consistiu no romance feito de digressões, Ítalo Calvino assinala que "[a] divagação ou digressão é uma estratégia para protelar a conclusão, uma multiplicação do tempo no interior da obra, uma fuga permanente; (...)".${ }^{14}$ Para o escritor italiano Carlo Levi, seria uma fuga da morte, explica Calvino. Essa digressão possibilita observar duas operações sobre a continuidade e a descontinuidade do tempo - o tempo "real" versus o tempo narrativo. Por sua vez, a digressão conjuga outro elemento igualmente imprescindível nesse tipo de estratégia narrativa que se interrompe a todo momento. Trata-se da iteração, da repetição.

Por seu turno, o filósofo Clément Rosset, ao refletir sobre os processos da repetição, observa que duas concepções da repetição engajam, nos planos filosófico e psicanalítico, uma visão inteiramente diferente do exercício da vida. Por isso o ensaísta francês distingue:

1. A repetição mecânica, patológica, ou repetição-lugar-comum. Ela significa rigorosamente o retorno do mesmo. Concepção pessimista no plano filosófico (Eclesiastes, Schopenhauer), e patológica no plano psicanalítico (instinto de morte, compulsão de repetição, ato falho).

2. A repetição operante, ou repetição diferencial, que significa retorno de um elemento diferente a partir de uma intenção do mesmo. Concepção trágica no plano filosófico (pluralismo irredutível a qualquer unidade ou síntese, mas que é ao mesmo tempo trágico e jubilatório,

${ }^{14}$ CALVINO, 1994, p. 59. 
tanto nos Gregos quanto na teoria nietzscheana do eterno retorno), e terapêutica no plano psicanalítico (acesso a um comportamento "normal"). ${ }^{15}$

A repetição $\mathrm{n}^{\circ} 1$, que significa o retorno do mesmo, também nos remete à questão da circularidade presente em várias obras de França Júnior. Conforme relata Malcolm Silverman, o autor, desde O viúvo, demonstra uma preferência por essa simetria circular sobretudo em relação ao espaço. Pedro, o narrador-protagonista, faz companhia à sua esposa que se encontrava hospitalizada, e explica logo nas primeiras linhas: "No momento em que ela [Darcy] morreu eu estava sentado ao lado de sua cama" (p. 15). E, no final do romance, ele também se encontra hospitalizado, após o incidente em que agride um motorista no trânsito, e reflete: "Nem reparo quando o médico e a enfermeira passam entre a cama e a parede, mas escuto sem que fizesse força para ouvir: 'Ele tem uma expressão tão calma'” (p. 146). Ambas as situações apresentam uma circularidade que reafirma o valor do espaço ao mesmo tempo em que destacam uma cena diferente, em que aparece ora a personagem, Darcy, ora o narrador-personagem, o Sr. Pedro.

No que concerne à repetição $\mathrm{n}^{\circ} 2$, ou repetição diferencial, é oportuno ressaltar, aqui, o ensaio "Jorge, um brasileiro: herói absurdo ou passageiro da esperança?", da ensaísta Melânia Silva de Aguiar, que enfatiza a importância na obra de Oswaldo França Júnior da filosofia existencialista de Sartre e de outras correntes literárias e filosóficas próximas ao horizonte literário do escritor. ${ }^{16}$ Dessa maneira, a autora aponta para a presença marcante de Albert Camus na formação literária de Oswaldo França Júnior. A busca de uma explicação para a existência se dá por meio de um intermitente questionamento, pelo exercício da consciência desperta. Só para citar alguns exemplos, vejamos o que diz Camus, em "O mito de Sísifo":

É durante esse retorno, essa pausa, que Sísifo me interessa. Um rosto que pena, assim tão perto das pedras, é já ele próprio pedra! Vejo esse homem redescer (sic), com o passo pesado mas igual, para o tormento cujo fim não conhecerá. Essa hora que é como uma respiração e que ressurge tão certamente quanto sua infelicidade, essa hora é aquela da

${ }^{15}$ ROSSET, 1989, p. 75.

${ }^{16}$ AGUIAR, 1993, p. 48-57. 
consciência. A cada um desses momentos, em que ele deixa os cimos e se afunda pouco a pouco no covil dos deuses, ele é superior ao seu destino. É mais forte que seu rochedo. ${ }^{17}$

Melânia Silva de Aguiar, ao destacar dois importantes elementos nessa repetição "ad aeternum", assim reflete sobre essa tomada de consciência, presente no mito de Sísifo, e que reconfigura a inutilidade do esforço humano:

Encontra-se aí na verdade a primeira proposição da noção de "absurdidade", ou seja, da tomada de consciência pelo ser humano da falta de sentido de sua condição. Retomando o mito de Sísifo para simbolizar o estudo da existência humana, Camus se detém em dois de seus elementos: a gratuidade do trabalho executado por Sísifo, escalando o rochedo e fazendo rolar ao infinito a pedra que dele se despenha, com toda a sua carga de absurdo ("não existe punição mais terrível do que o trabalho inútil e sem esperança”) e a consciência deste absurdo, revelada no momento do retorno à planície em busca novamente da pedra, "ad aeternum". ${ }^{18}$

Esses dois elementos ressaltados pela estudiosa, postos em relevo pela releitura de Camus, a respeito do mito de Sísifo, nos permite relacioná-los com a fala da personagem Jorge, do romance Jorge, um brasileiro, de Oswaldo França Júnior, que corrobora o exercício dessa instigante tomada de consciência: "E o serviço que eu fazia naquela época lá da estrada, eu ainda era capaz de fazer do mesmo modo ou até melhor. A única coisa que eu sabia que estava diferente era aquilo de ficar pensando tanto. Antes eu não pensava" (p. 93, grifos acrescentados). Assim, a repetição mecânica leva à repetição diferencial por meio de uma ruptura. O "antes" e o "depois" do pensamento evidenciam a conquista da própria identidade, que se estrutura sobre a autonomia dos atos do protagonista.

Postura semelhante à da personagem Jorge assume o personagemnarrador de $A$ volta para Marilda, quando recorda sua relação com a exmulher, Rozana:

17 CAMUS, 1989, p. 143.

18 AGUIAR, 1993, p. 53. 
Puxa, como já fui bobo nessa vida. Como já fiz coisa sem sentido. E o pior é que só depois da coisa ter passado é que eu vejo. Depois de já ter perdido muito tempo. Agora, pelo menos, estou aprendendo. Tenho este consolo. Agora, pelo menos, já penso, raciocino. O que já é alguma coisa. Antes nem pensar eu pensava. Ia fazendo. Achava que uma coisa era de um modo e não parava um minuto para ver se podia ser de outro. Agora não, eu paro, vejo. Raciocino. Também, se não fosse assim, eu podia até desistir. Não ia dar nem para entender. Levar tanto na cabeça, perder tanto tempo, e no fim continuar do mesmo modo? Sem tirar proveito nenhum? Aí não, aí era para desanimar. Mas a gente aprende. Aos poucos. Eu pelo menos sei que tenho aprendido. Ainda faço das minhas por aí mas não são mais iguais àquelas que eu fazia antes. (p. 20. Grifos acrescentados).

Convém retomar aqui mais algumas palavras da personagem Jorge que, ao mesmo tempo em que se compraz com o processo de tornar-se autônomo, independente, sente-se perplexo diante dessa mudança que o faz sentir-se um novo sujeito:

Não me lembro de naquele tempo ficar assim pensando, e sentindo raiva ou precisando desviar o pensamento para não achar as coisas mais erradas ainda. Sei que toda pessoa vai mudando, mas digo para você que as mudanças de alguns você nota na hora que olha, e eu sei que mudei e que vou mudando, mas é só no pensamento. Você não seria capaz de dizer se eu estava mudado, só olhando assim para mim, sem que a gente conversasse. E não sei qual mudança é maior. Digo para você que não sei, que fico na dúvida (p. 60).

Essa nova postura frente à vida, e do domínio dos próprios pensamentos, contrasta com um outro conto de França Júnior que merece ser transcrito a seguir, como forma de se estabelecer uma comparação entre o mito de Sísifo e a utopia de quem só faz o que os outros ensinam, como exemplo daqueles que só imitam e não demonstram pensar:

\section{A felicidade}

Ensinaram-lhe que ali, naquele sítio, é que ele encontraria o pedaço de felicidade. E agora lá está ele: as mãos crispadas nas reentrâncias do rochedo e o corpo fustigado pelo vento. Seus olhos não saem do pedaço da felicidade.

Temos certeza de que acabará soltando uma das mãos para apanhar a felicidade e aí cairá do rochedo. E nós veremos o vento levar um homem com a felicidade nas mãos. (p. 59). 
Esse conto, presente em As laranjas iguais, parece sugerir um Sísifo às avessas. Apesar da persistência dessa personagem e do enorme grau de ilusão que embala suas atitudes, o que se vislumbra é um homem na iminência da queda, e não a pedra que se despenha, como no mito que conhecemos. Mas há algumas conexões entre os dois textos que merecem ser assinaladas, especialmente se voltarmos ao Sísifo relido por Camus. Neste, vemos um "rosto crispado" pelo esforço de retornar com a pedra, bem diferente do momento em que a personagem desce para buscá-la novamente, pois esse momento sublime oferece a Sísifo a possibilidade de pensar sobre a sua condição, sozinho, sem ouvir o que os outros dizem. Por isso a ênfase recai sobre o seu rosto, sede (e sede com e fechado) de pensamentos.

Neste caso, vê-se apenas todo o esforço de um corpo estirado para levantar a pedra enorme, rolá-la e fazê-la subir uma encosta, tarefa cem vezes recomeçada. Vê-se o rosto crispado, a face colada à pedra, o socorro de uma espádua que recebe a massa recoberta de barro, e de um pé que a escora, a repetição na base do braço, a segurança toda humana de duas mãos cheias de terra. Ao final desse esforço imenso, medido pelo espaço sem céu e pelo tempo sem profundidade, o objetivo é atingido. Sísifo, então, vê a pedra desabar em alguns instantes para esse mundo inferior de onde será preciso reerguê-la até os cimos. E desce de novo para a planície. ${ }^{19}$

O conto de França Júnior, por outro lado, destaca a expressão "as mãos crispadas". O substantivo "mãos" é repetido três vezes, ao passo que Camus fala apenas uma vez em duas mãos cheias de terra (embora enfatize "a segurança toda humana" de que são portadoras). Isso nos lembra a oposição entre o trabalho intelectual e o trabalho manual. Neste, destacam-se a técnica, a habilidade, ou simplesmente a obediência, ou cumprimento de ordens. Não é por acaso que a personagem do conto sai em busca de uma ilusão ensinada por "outros" (ensinaram-lhe: sujeito indeterminado). Bem diferente do sujeito que sabe o que faz, o que pensa. É o que nos revela a segunda parte do conto, em que um "nós" subentendido marca o posicionamento do narrador: "Temos certeza de que acabará soltando uma das mãos para apanhar a felicidade e aí cairá do rochedo."

${ }^{19}$ CAMUS, 1989, p. 142 (grifos acrescentados). 
Ainda a seu turno, o conto parece reverter o mito de Prometeu acorrentado. Neste, Prometeu é atado a um rochedo por haver desobedecido aos deuses, roubando-lhes uma faísca do fogo celeste. Com esse fogo o homem foi dotado da razão e da faculdade de cultivar a inteligência, as ciências e as artes. Decidido a não revelar os segredos que conhece e guarda, Prometeu resiste ao suplício de continuar preso ao rochedo. Diante dessa atitude, Mercúrio, filho e emissário de Júpiter, comunica-lhe que ele teria seu suplício aumentado pelo abutre que viria, durante todos os dias, perfurar-lhe o fígado, até que fosse precipitado nos abismos do Tártaro. A personagem do conto de França Júnior também se encontra presa a um rochedo à procura de um pedaço de felicidade. No entanto, ele não enfrenta uma punição por um ato ilícito praticado anteriormente. O preço a pagar é, então, duplo: a necessidade de usar as mãos para pegar essa felicidade, as mesmas mãos que garantem o suporte do corpo. Por isso, ao tentar apanhar a felicidade, será levado pelo vento, mesmo que consiga levar a felicidade nas mãos. Mas, o resultado será duplamente desastroso: é um homem que cairá com a felicidade nas mãos. Tal como o Prometeu que cairá com o segredo dos Deuses, sob o peso da pesada pedra a que se acha acorrentado. Mas não será uma pedra como a que proporciona a Sísifo tornar-se senhor de seu destino.

Essa pedra de Sísifo lembra a mesma pedra de toque que permite vislumbrar a atitude determinada da personagem Jorge, no momento da partida, assim que recebe as ordens do patrão. Já dentro do ônibus, ele reflete: "E me lembro que eu olhava para fora, no escuro, e forçava a vontade, dizendo que ia trazer aqueles caminhões até Belo Horizonte no prazo certo nem que tivesse que puxar um por um no ombro (p. 31, grifos acrescentados). Essa é uma prova contundente de que a pedra de Sísifo pode ser comparada aos caminhões que Jorge tem a incumbência de trazer no prazo determinado pelo patrão. Aliás, não é somente uma pedra - é uma pedra que se transmuta em oito carretas, com trinta toneladas de milho cada uma delas. Na opinião de João Luiz Lafetá, essa é também uma característica da modernidade da obra de França Júnior: "homens que enfrentam as dificuldades da vida e conseguem vencê-las pela habilidade técnica, pelo conhecimento da profissão, e sobretudo pela energia indomável transformada em produtividade." ${ }^{20}$ Assim, a viagem de Jorge

${ }^{20}$ LAFETÁ, 1983, p. 207. 
através de Minas Gerais sugere um antigo rito de virilidade, levando-o a encarar frente a frente todo tipo de desafio, entre os quais a chuva torrencial que arruína as estradas, impedindo o livre fluxo das carretas que devem seguir e têm dia marcado para a entrega das cargas de milho.

Antônio Olinto chama a atenção para o fato de que o pioneirismo rodoviário de França Júnior "está ligado a um processo muito antigo de narração: as viagens de um para outro lugar, as peregrinações, os regressos." ${ }^{21}$ Viagens e regressos: isso nos remete à circularidade constituinte da obra mais famosa de França Júnior. O que importa destacar, em Jorge, um brasileiro, é que há uma circularidade que é exposta através das frases iniciais e finais da narrativa. Logo na primeira linha do romance, o narrador está relembrando o passado em companhia da mulher de seu patrão: "...Você sabe como é. E ela se sentou na minha frente e cruzou as pernas" (p. 19). As reticências marcam bem um vazio, um silêncio a interromper uma fala que volta a se fazer ouvir. Uma fala que se dirige a um "você", no estilo bem informal das narrativas orais. E lá pela antepenúltima página, o narrador completa o círculo de sua narrativa, retomando a declaração inicial: "E ela falou e riu. E você sabe como é. Depois se sentou na cadeira em frente da que eu tinha me sentado, e cruzou as pernas, e continuou falando" (p. 191). Apesar da semelhança entre as frases, o que vemos, ao final da obra, é uma personagem totalmente diferente daquela que começa a relatar sua travessia.

O sentido conotativo suscitado pelo verbo "cruzar" é bem expressivo nesse romance: a atitude de "cruzar as pernas", mais do que uma insinuação por parte da dona Helena, esposa do Sr. Mário ("E continuava sentada, com as pernas cruzadas e o vestido branco deixando ver até em cima." - p. 192.), reflete o "cruzamento das narrativas", em que o tempo linear e cronológico da viagem se entrecruza com o tempo circular da narrativa e o tempo psicológico da personagem Jorge. A duplicidade que se observa resulta nesse entrelaçamento produzido pelas cenas rememoradas que se cruzam em diversas passagens relatadas pelo narrador.

Jorge empreende um trabalho hercúleo para tentar cumprir uma missão no tempo definido pelo patrão. As dificuldades, no entanto, são inúmeras, por causa das chuvas, também intermitentes. Entre uma chuva

${ }^{21}$ OLINTO, apud FRANÇA JÚNIOR, 1967, p. 16. 
e outra, Jorge encontra soluções viáveis, com a ajuda dos companheiros de viagem. Infelizmente, quando ocorre a chegada triunfal em Belo Horizonte, quase às dez horas da noite, das oito carretas carregadas com trinta toneladas de milho cada uma, já era tarde demais. E, a partir daí, o que deveria ser a recompensa do herói, passa a se desenvolver no relato de uma difícil empreitada. O herói não conseguiu chegar a tempo da inauguração da refinaria, entretanto sente-se gratificado por estar vivo e por assumir sua condição humana ao realizar uma missão praticamente impossível.

Ao chegar da exaustiva viagem, Jorge se dirige ao escritório do Sr. Mário. Em seu retorno as coisas haviam-se modificado bastante: o chuveiro estava estragado; a cama onde ele dormia estava interditada pelo Sr. Mário. Mas ele dorme nela assim mesmo. Quando acordou e foi apanhar a chave da Kombi, não a encontrou e foi falar com o vigia. Ele lhe respondeu que a ordem era para "ninguém mexer em nada ali" (p. 189). Mas entregoulhe a chave e ele seguiu em direção ao escritório. O chefe não está, e quem o recebe é Rui, o contador que, ironicamente, lhe diz que o Sr. Mário estava querendo muito "bater um papo" com ele. A seguir, lhe dirige várias perguntas sobre aquele atraso e sobre o fato de levar "tantos dias para trazer uns caminhões da Rio-Bahia até Belo Horizonte" (p. 189), insinuando uma série de dúvidas a respeito da demora da viagem e pedindo-lhe todas as notas referentes às despesas efetuadas. Jorge vai despejando os papéis referentes à viagem, que estavam em seu bolso, e atira-os no rosto do contador. Não satisfeito com isso, começa a agredilo brutalmente.

- Seu merda. Olhe aqui, seu pedaço de merda.

E fui empurrando-o, e ele na ponta dos pés, e eu sentindo que ele estava tremendo. E fui empurrando e dizendo para ele que ele era um pedaço de merda. E eu querendo falar mais coisas, mas não achando. E chegamos na porta que dava para a sala do senhor Mário. Então eu o suspendi pelo paletó e o joguei contra a porta. Ela deu um estalo, abriu e rodou batendo contra a parede. E caíram pelo chão pedaços de ferro do trinco que quebrou, e vidros, da parte de cima que não era de madeira.

E o contador ficou parado onde tinha batido, com os braços na frente do queixo. Segurei de novo seu paletó e tornei a ir empurrando-o, agora em direção da sua mesa, e dizendo para ele que ele era um merda, um pedaço de merda. E bati com ele na parede e ele não falou nada. Só ficou com as mãos na frente do rosto e tremendo. Bati de novo 
e o soltei, e ele caiu. E eu o chutei, e ele se levantou, correu e ficou se espremendo contra a parede, e olhando para mim. Aí saí dali, e fui andando e ninguém falou nada (p. 190-191).

O trecho destacado exemplifica o uso da violência praticada contra uma vítima expiatória. Além disso, pode-se perceber uma reiteração dos impropérios nos dois parágrafos que narram a cena. As cenas se repetem tanto com os recursos verbais quanto com os atos violentos. Dessa forma, verifica-se uma repetição que se dá em vários níveis: na linguagem, na estrutura narrativa, nos gestos rituais, na presença do tema do duplo e na recorrência do tema da violência em algumas obras de França Júnior.

Esse episódio é de fundamental importância, pois é ele que efetiva realmente a "libertação" da personagem. Na situação em pauta, espancar o contador significa agredir o patrão, o que anuncia o desfecho do romance, no qual Jorge se liberta das amarras que o mantinham submisso ao Sr. Mário. É relevante ressaltar, nesse contexto, a afirmação de Daniel Bougnoux, quando descreve o advento do duplo como a dicotomia entre a mônada psíquica e o "outro", que representa a ameaça e a perseguição:

A primeira polarização do mundo em bom/mau, feita pela mônada psíquica, faz surgir o alter ego ou o duplo (daí, há de surgir a reciprocidade, o vínculo social, o amor, o respeito, o altruísmo, etc.), mas marcado pelo selo da ambivalência. O outro é (um) eu, mas esse outro eu só pode ser um malvado todo-poderoso. Tal seria a via pela qual a psique negocia sua soberania primitiva e aceita compartilhar o mundo. ${ }^{22}$

Se a relação conflitiva entre o indivíduo e seu duplo, ou entre o indivíduo e o outro, é responsável pelo surgimento da "reciprocidade, do vínculo social, do amor, do respeito e do altruísmo", ela também daria origem à violência. No momento em que Jorge vê o patrão refletido na pessoa do contador, ele começa a distinguir a si mesmo de um outro que lhe aparece como "malvado todo-poderoso". Dessa forma, ele opera uma transgressão e se transforma em senhor de si mesmo. Esse episódio lhe propicia um novo ânimo, sempre crescente, sobretudo ao retomar o fio da narrativa, frente à esposa do Sr. Mário. Jorge deseja esclarecer tudo para o patrão, mas não o encontra em casa. E fica ali, sentado, ouvindo a dona

22 BOUGNOUX, 1994, p. 144. 
Helena falando, fumando, com as pernas cruzadas. Enfim, desiste de esperá-lo. Não sem antes realizar um gesto supremo de libertação: beijar a esposa do patrão.

Levantei-me e, então, fiquei sabendo o que é que eu estava querendo fazer desde que a tinha visto cruzar as pernas com aquele modo de mulher fina. E fui, e cheguei perto dela. E ela se levantou e ficou olhando para mim. E cheguei perto, e não falei, e ela tinha parado de falar. E passei o braço em volta dela e ela não fez nada. Ficou me olhando com os braços caídos, e o cigarro aceso na mão. Apertei-a e senti o corpo dela se encostando em mim. E com a mão nas suas costas, virei o corpo e sua boca veio e eu a beijei com força. (...) E digo que nunca beijei uma mulher como aquela. (p. 192-193).

Em seguida ele sai, tropeça em algo e pára. "Mas só para esperar que a coisa acabasse de cair" (p. 193). E não abaixa nem apanha o que caíra. Vai saindo e fecha a porta. Aqui se encerra também uma fase daquele sujeito subalterno. Jorge não é mais o mesmo. Esperar que a coisa acabasse de cair registra o exato momento da mudança. Enfrentar violentamente o contador, duplo do patrão, beijar D. Helena, consorte do dominador, torna Jorge senhor de sua própria história. A violência contra o funcionário termina por adquirir um valor positivo, pois, através dela, Jorge se afirma como sujeito. Quando sai da casa do Sr. Mário, ele vai direto à garagem dos concreteiros: "e peguei minhas coisas que eram poucas, e coloquei tudo dentro das minhas duas bolsas, e saí dali” (p. 193). Uma saída definitiva, mas que não aponta para um ponto final:

E digo para você que não gosto mais nem de me lembrar dessas coisas, e só me lembro mesmo, quando alguém chega e a gente fica batendo papo. Porque, você sabe, a gente não consegue ficar conversando muito tempo, sem no fim falar do que a gente já fez, ou do que a gente já foi. (p. 193).

A repetição diferencial, de que nos fala Clément Rosset, é perfeitamente perceptível nessa atitude de Jorge: no plano do enunciado, ele liberta-se de sua submissão ao patrão; no plano da enunciação, a história não se repete de forma idêntica. Jorge é, agora, sujeito de sua própria história e dono da narração dela. A diferença através da repetição acontece de fato. Observe-se, com esses exemplos, como a questão da repetição adquire contornos importantes, uma vez que não mais se situa num nível tipológico, centrada única e exclusivamente na semelhança, 
mas alcança uma significância mais abrangente e extensa pelo fato de a repetição se dar no nível das semelhanças e, simultaneamente, provocar o insólito da diferença. É uma repetição que ocorre também no nível da enunciação. No entanto, fica a cargo do leitor perseguir esses fios, imaginando um Jorge que se vai por aí, com suas duas bolsas, engendrando suas repetições, seus duplos, suas duplicidades.

A título de conclusão, convém retomar aqui os três romances que escolhemos para estudar neste ensaio e comparar a técnica narrativa neles desenvolvida. Em Os dois irmãos, a duplicidade acontece de forma paralela: ora é relatado o encontro com o irmão, ora se lê a conversa com a esposa. O narrador de $A$ volta para Marilda se apresenta de forma dissimulada, conta uma história que na verdade é bem outra, desembocando numa narrativa vacilante: ora temos um narrador ardiloso, ora uma falsa Marilda. E a duplicidade que consiste no entrelaçamento de uma história se encaixando na outra, de um caso-puxa-caso, que retoma o relato interrompido, numa repetição intermitente, que culminará na cena final de Jorge, um brasileiro.

\section{Referências Bibliográficas}

AGUIAR, Melânia Silva de. Jorge, um brasileiro: herói absurdo ou passageiro da esperança? Revista de Estudos de Literatura. Belo Horizonte: CEL, FALE/ UFMG, v. 1, n. 1, p. 48-57, out. 1993.

BOUGNOUX, Daniel. Introdução às ciências da informação e da comunicação. Trad. Guilherme João de Freitas Teixeira. Petrópolis: Vozes, 1994.

CALVINO, Ítalo. A rapidez. Seis propostas para o próximo milênio. 2. ed. Trad. Ivo Barroso. São Paulo: Companhia das Letras, 1994.

CAMUS, Albert. O mito de Sísifo: ensaio sobre o absurdo. Trad. Mauro Gama. Rio de Janeiro: Editora Guanabara, 1989.

DOsTOIEVSKI, Fiodor M. Le double. Trad. Gustave Aucouturier. Paris: Gallimard, 2002.

ESSLIN, Martin. From Doppelgängers to Doubles in Drama. Stanford French Review, Stanford, CA, v. 8, n.1, p. 35-46, Spring, 1984.

FRANÇA JÚNIOR, Oswaldo. Jorge, um brasileiro. Rio de Janeiro: Sabiá, 1967.

FRANÇA JÚNIOR, Oswaldo. Jorge, um brasileiro. 12. ed. Rio de Janeiro: Nova Fronteira, 1988. 
FRANÇA JÚNIOR, Oswaldo. A volta para Marilda. 3. ed. Rio de Janeiro: Nova Fronteira, 1986.

FRANÇA JÚNIOR, Oswaldo. Os dois irmãos. Rio de Janeiro: Rocco, 1976.

FRANÇA JÚNIOR, Oswaldo. As laranjas iguais(contos). 2. ed. Rio de Janeiro: Nova Fronteira, 1996.

LAFETÁ, João Luiz. O romance atual (Considerações sobre Oswaldo França Júnior, Rui Mourão e Ivan Ângelo). Anais do Seminário de ficção mineira II - de Guimarães Rosa aos nossos dias. Belo Horizonte: Imprensa Oficial, 1983. p. 197-219.

LOPES, Maria Angélica Guimarães. Dupla construção: A volta para Marilda, de Oswaldo França Júnior. Brasil-Brazil: Revista de Literatura Brasileira-A Journal of Brazilian Literature. Porto Alegre: Mercado Aberto, p. 21-32, 1991.

PARKER, John M. Técnica narrativa em Oswaldo França Júnior. Boletim do $C E S P$, v. 16, n. 20. Belo Horizonte: Faculdade de Letras da UFMG, p.141-148, jan./dez. 1996.

PARKER, John. Les romans d'Oswaldo França Júnior en rétrospective. Disponível em http://bresil.org/Litterature_en_francais/Oswaldo Acesso em:22 nov. 2002.

PEREIRA, Vera Lúcia Felício. Mimese: o ardil em O passo-bandeira. Uma história de aviadores. Revista do Centro de Ciências Humanas da PUC-MG. Belo Horizonte: FUMARC/PUC-MG, v.1, p. 9-23, 1983.

ROSSET, Clément. Lógica do pior. Trad. Fernando J. Fagundes Ribeiro e Ivana Bentes. Rio de Janeiro: Espaço e Tempo, 1989. p. 61-79.

SCHÖLLHAMMER, Kark Erik. O monstruoso e o indizível - notas sobre a relação entre violência e literatura a partir de um conto de Sérgio Sant'anna. Comunicação Epolítica, Rio de Janeiro, n. s., v. 1, n. 2, p. 281-292, dez. 1994 - mar. 1995.

SILVERMAN, Malcolm. O mundo ficcional de Oswaldo França Júnior. Moderna ficção brasileira. Trad. João Guilherme Linke. Rio de Janeiro: Civilização Brasileira; Brasília: INL, 1978. p. 190-208. 


\section{Resumo}

Reflexões sobre a duplicidade na técnica narrativa desenvolvida por Oswaldo França Júnior, através da qual são enredadas as tramas em três de seus romances. A análise destaca também a complexa relação com o motivo do duplo e seus desdobramentos em repetição, violência, artifício, circularidade e diferença.

\section{Resumé}

Ce texte présente quelques réflexions sur la duplicité dans la technique narrative développée par Oswaldo França Júnior, à travers laquelle les trames sont embrouillées en trois de ses romans. L'analyse met aussi en évidence la complexe relation avec le motif du double et ses dédoublements en répétition, violence, artifice, circularité et différence. 